\title{
Post-ingestive effects of flavonoids in the midgut epithelium of Anticarsia gemmatalis (Hübner 1818) (Lepidoptera: Erebidae) larvae
}

\section{Efeitos pós-ingestivos de flavonóides no epitélio do intestino médio de larvas de Anticarsia gemmatalis (Hübner 1818) (Lepidoptera: Erebidae)}

\author{
Norberto Aparecido Cruz ${ }^{1}$, Clara Beatriz Hoffmann-Campo², Sheila Michele Levy ${ }^{3}$, Angela \\ Maria Ferreira Falleiros ${ }^{4}$
}

\begin{abstract}
An alternative control to soybean caterpillar has been the use of insect resistant plants that present phenolic flavonoids. The midgut is the main access pathway of food and chemical substances ingested. The present study examined morphological alterations in the midgut epithelium of the soybean caterpillar, after the ingestion of soybean genotypes containing the flavonoids rutin and genistin. The caterpillars and genotypes (BRS 257 - control, BR 16, Dowling, PI 229358, IAC 100 and PI 227687) were obtained from the insect rearing facility at the Embrapa Soja. The midguts were collected, fixed in Karnovsky, processed and analyzed under a light microscope. All treatments caused alterations in the midgut epithelial cells. These alterations in the columnar cells were more assiduous than the on other cell types, showing an increase of cytoplasmic protrusions and vacuoles. The goblet cells showed few changes for all genotypes tested, while the regenerative cells presented alterations mainly for the Dowling and PI 227687 treatments. The peritrophic membrane was absent for genotypes IAC100 and PI 227687. We conclude that the Dowling and PI 227687 genotypes were effective and promoted great morphological alterations in the midgut of the soybean caterpillars, being able to be very effective for the control of this plague.
\end{abstract}

Keyword: Soybean caterpillar. Morphology. Digestive tract. Rutin and genistin.

\section{Resumo}

Um controle alternativo para a lagarta da soja tem sido o uso de plantas resistentes a insetos que contém flavonoides fenólicos. O intestino médio é a principal via de acesso do alimento e substâncias químicas ingeridas. O presente estudo examinou as alterações morfológicas no epitélio do intestino médio da lagarta da soja, após a ingestão de genótipos de soja contendo os flavonoides rutina e genistina. As lagartas e os genótipos (BRS 257 - controle, BR 16, Dowling, PI 229358, IAC 100 e PI 227687) foram obtidos do laboratório de criação de insetos da Embrapa Soja. Os intestinos médios foram coletados, fixados em Karnovsky, processados e analisados ao microscópio de luz. Todos os tratamentos causaram alterações nas células epiteliais do intestino médio. As alterações foram mais assíduas nas células colunares do que nos demais tipos celulares. Essas apresentaram grande quantidade de protrusões citoplasmáticas e de vacúolos. As células caliciformes apresentaram poucas alterações para todos os genótipos testados, enquanto as células regenerativas apresentaram alterações principalmente nos tratamentos Dowling e PI 227687. A membrana peritrófica estava ausente para os genótipos IAC100 e PI 227687. Conclui-se que os genótipos Dowling e PI 227687 foram bastante efetivos e promoveram grandes alterações morfológicas no intestino médio das lagartas da soja, podendo ser bastante eficaz para o controle desta praga.

Palavras chave: Lagarta da soja. Morfologia. Tubo digestivo. Rutina e genistina.

${ }^{1}$ Doutorado em Agronomia pela Universidade Estadual de Londrina. Centro de Ciências Agrárias, Universidade Estadual de Londrina; Londrina, Paraná, Brasil.

${ }^{2}$ Doutorado em Botânica pela The University Of Reading, Grã-Bretanha. Empresa Brasileira de Pesquisa Agropecuária, Centro Nacional de Pesquisa de Soja; Londrina, Paraná, Brasil.

${ }^{3}$ Doutorado em Ciências Biológicas (Zoologia) pela Universidade Estadual Paulista Júlio de Mesquita Filho. Centro de Ciências Biológicas, Departamento de Histologia, Universidade Estadual de Londrina; Londrina, Paraná, Brasil.

${ }^{4}$ Doutorado em Ciências Biológicas (Anatomia Humana) pela Universidade Estadual Paulista Júlio de Mesquita Filho. Centro de Ciências Biológicas, Departamento de Histologia, Universidade Estadual de Londrina; Londrina, Paraná, Brasil. E-mail: angefal@gmail.com 


\section{Introduction}

Insect pests are one of the main yield reducing factors in different cultivated plant species. The soybean caterpillar, Anticarsia gemmatalis (Hübner, 1818) (Lepidoptera: Erebidae), is considered the main foliage feeding pest of soybean in Brazil, causing great damage to this crop. To reduce the costs of production and negative environmental impacts in Brazil, efforts have been made to develop alternative methods to control this caterpillar and other soybean insect-pests (HOFFMANN-CAMPO; HARBONE; MCCAFFERY, 2001). Genotypes resistant to insects are considered an ideal method of control, since the insect population can be reduced, but not causing considerable damage in the field and to environment. Furthermore, it doesn't require adopting sophisticated technology for the producers and with low production costs (LARA, 1991).

Resistance to insects is mainly due to chemical substances (allelochemicals) present in the host plants, such as alkaloids, flavonoids, terpenoids, sterols, etc. (KUBO; HANKE, 1986). In soybean, the probable defense substances are the flavonoids that are generally more abundant in pest-resistant genotypes. These flavonoids form a group of natural substances that have various biological activities (HOFFMANNCAMPO, 1995).

Tests of food preferences on A. gemmatalis were developed and the researchers observed that the genotypes BR82-12547, IAC74-2832, PI 227687 and PI 274454 were the most rejected by the caterpillars (HOFFMANN-CAMPO; MAZZARIN; LUSTOSA, 1994). Later seven flavonoids were identified in PI 227687 (HOFFMANN-CAMPO, 1995), a genotype widely used in breeding programs as source of resistance to insects, indicating toxicity in this cultivar and could explain the rejection by the insect. Among the phenolic compounds identified, the flavonoid rutin and the isoflavonoid genistin are recognized as playing an important role in the defense of soybean to lepidopteran insects. Previous studies of these substances have shown an antibiotic and/or non-edible effect in larvae of various insect pests (HOFFMANNCAMPO, 1995; HOFFMANN-CAMPO; HARBONE; MCCAFFERY, 2001; STAMP; SKROBOLA, 1993).

The action of these substances begins when the caterpillar ingests the soybean leaves; the digestion occurs on the digestive tract, especially on the midgut, the principal region of the absorption of food and chemical-biological substances (CHAPMAN, 2013; TERRA; FERREIRA, 1991). Levy et al. (2004, 2009) and Levy (2005), have studied the internal morphology of digestive tract of the A. gemmatalis for years, especially with insects infected with nucleopolyhedrovirus $A g \mathrm{MNPV}$, but there are no reports of the acting of flavonoids in midgut epithelium. Thus, the objective of the present study was to investigate the alterations caused by soybean genotypes with different rutin and genistin concentrations on the midgut epithelium of these insects.

\section{Material and Methods}

Resistant soybean plants tested in this experiment were the genotypes BRS 257 (control), BR 16, Dowling, PI 229358, IAC 100 and PI 227687 (table 1). They were produced under greenhouse conditions (mean temperature $23 \pm 2{ }^{\circ} \mathrm{C}$, mean relative humidity $78 \%$ ) at the Empresa Brasileira de Pesquisa Agropecuária Embrapa Soja, Londrina, Paraná State, Brazil.

Table 1 - Genealogy of the soybean genotypes used and the rutin and genistin concentrations.

\begin{tabular}{llccc}
\hline $\begin{array}{l}\text { Treatments } \\
\text { Genotypes }\end{array}$ & \multicolumn{1}{c}{ Genealogy } & \multicolumn{2}{c}{ Concentration (mg/g } \\
x 10-2) \\
\hline BRS 257 & BR93-32109 x BR94-23396 & Rutin & Genistin \\
\hline BR 16 & $\begin{array}{l}\text { D69-1310-M58 (D49-772 } \\
\text { 2491) x 'Davis' }\end{array}$ & D49- & 0.0 & 0.0 \\
Dowling & Semmes x PI 200492 & & 0.16 \\
PI 229358 & Tóquio, Japão & 0.0 & 4.29 \\
IAC 100 & 'IAC 12' x IAC 78-2318 & 2.12 & 1.36 \\
PI 227687 & Okinawa, Japão & 9.72 & 1.42 \\
\hline
\end{tabular}

Source: Valle e Lourenção (2002).

The leaves were collected, washed in $5 \%$ sodium hypochlorite solution, rinsed in distilled water and kept in an acrylic box containing $A$. gemmatalis eggs. The eggs were also supplied by the entomology laboratory at Embrapa Soja. To obtain the eggs, the larvae were maintained in the laboratory on an artificial diet (HOFFMANN-CAMPO; OLIVEIRA; MOSCARDI, 1985), under controlled temperature $\left(25-27^{\circ} \mathrm{C}\right)$, photoperiod $(14 \mathrm{~L} / 10 \mathrm{D})$ and $80 \%$ relative humidity. 
After hatching, the larvae were observed daily until $2^{\text {th }}$ instar when they were placed in 6 acrylic boxes containing 25 larvae/box. The larvae were continuous fed with leaves until the $4^{\text {th }}$ instars $(10-12$ days of development) and the leaves were substituted every 12 hours there is no lack of food to the insects. In $4^{\text {th }}$ instar the larvae were dissected in insect saline solution (ISS$1.80 \mathrm{~g}$ de $\mathrm{NaCl} ; 1.88 \mathrm{~g}$ de $\mathrm{KCl} ; 0.16 \mathrm{~g}$ de $\mathrm{CaCl} ; 0.004 \mathrm{~g}$ de $\mathrm{NaHCO}_{3}$; distillated water-q.s.p. $100 \mathrm{ml}$ ).

The midguts (25 per treatment) were fixed in glutaraldehyde $(2.5 \%)$ and paraformaldehyde $(4.0 \%)$ solution $(0.1 \mathrm{M}$ phosphate buffer, $\mathrm{pH}$ 7.3) for $6 \mathrm{~h}$, dehydrated in ethylic alcohol solutions and embedded in glycol methacrylate resin (Historesin ${ }^{\circledR}$-Leica), according to the manufacturer instructions.

The material was cut with glass knives in a rotary microtome (Leica RM 2145) and the sections with $3 \mu \mathrm{m}$ were stained with Haematoxylin-Eosin and analyzed in under a light microscope (Axiophot, Zeiss) at the Laboratório de Insetos/Departamento de Histologia/ Universidade Estadual de Londrina.

\section{Results}

The qualitative degree of the alterations caused by rutin and genistin in midgut of $A$. gemmatalis are shown in Table 2. In larvae treated with BRS 257 (control), the midgut wall presented an epithelial layer, covered by a peritrophic membrane and surrounded by a muscular layer (Fig. 1A).

All the genotypes tested caused damages in the epithelial cells The Dowling and PI 227687 genotypes caused the greatest alterations (Figs. 1C and 1F) in all midgut collected. The insects that fed PI 229358, BR 16 and IAC 100 (Figs. 1D, 1B and 1E) also showed the tube with morphological alterations, but these were punctual and more scarse. The treatments promoted morphological changes in columnar cells (Co), with intensely disorganized on the striated border (S) (Figs. $1 \mathrm{C}, 1 \mathrm{D}$ and $1 \mathrm{~F})$; great cytoplasmic vacuolization $(\mathrm{V})$ (Figs. 1B, 1C, 1D, 1E and 1F) and sometimes with total cell detachment in the direction of the intestinal lumen (L) (Figs. 1C, 1D and 1E).

In goblet cells $(\mathrm{Gc})$, all the treatments showed damages, especially Dowling and PI 227687, when we could detect cell voluminous and with an apparent increase in the quantity (Figs. 1C and 1F). Alterations qualitative were also observed in the regenerative cells (Rc) in insects fed with the BR16, Dowling and PI 227687 genotypes (Figs. 1B, 1C and 1F).
The peritrophic membrane $(\mathrm{Pm})$ showed changes in all treatments, as fragmentation and distance of epithelium observed in BR16, Dowling e PI229358 (Figs. 1B, 1C e 1D), or total absence as detected in IAC100 and PI227687 (Figs. 1E e 1F).

Table 2 - Qualitative assessment of the alterations caused by rutin $(\mathrm{R})$ and genistin $(\mathrm{G})$ in the midgut epithelium of A. gemmatalis larvae. Flavonoids concentrations in $\mathrm{mg} / \mathrm{g}$ $\mathrm{x} 10-2$.

\begin{tabular}{|c|c|c|c|c|c|c|c|}
\hline \multicolumn{8}{|c|}{ Genotypes } \\
\hline \multicolumn{2}{|l|}{ Structure } & $\begin{array}{c}\text { BRS257 } \\
\text { R: 0 } \\
\text { G:0 }\end{array}$ & $\begin{array}{c}\text { BR16 } \\
\text { R: } 0 \\
\text { G:0.16 }\end{array}$ & $\begin{array}{c}\text { Dowling } \\
\text { R: } 0 \\
\text { G:4.29 }\end{array}$ & $\begin{array}{c}\text { PI229358 } \\
\text { R: } 2.12 \\
\text { G: } 1.36\end{array}$ & $\begin{array}{c}\text { IAC100 } \\
\text { R:9.72 } \\
\text { G: } 1.42\end{array}$ & $\begin{array}{c}\text { PI227687 } \\
\text { R: } 36.82 \\
\text { G:1.22 }\end{array}$ \\
\hline \multicolumn{2}{|c|}{ Peritrofic membrane } & - & + & + & + & +++ & +++ \\
\hline \multirow{3}{*}{$\begin{array}{c}\text { Columnar } \\
\text { cells }\end{array}$} & $\begin{array}{l}\text { Striated } \\
\text { border }\end{array}$ & - & - & +++ & + & + & +++ \\
\hline & $\begin{array}{l}\text { Cytoplasm } \\
\text { cell }\end{array}$ & - & ++ & +++ & ++ & ++ & ++ \\
\hline & Protrusions & - & + & +++ & +++ & +++ & ++ \\
\hline \multicolumn{2}{|l|}{ Goblet cells } & - & ++ & +++ & ++ & ++ & +++ \\
\hline \multicolumn{2}{|c|}{ Regenerative cells } & - & + & ++ & + & + & ++ \\
\hline
\end{tabular}

Legend: Key (-) no alteration;(+) slight alteration;(++) moderate alteration; $(+++)$ strong alteration.

Source: Authors.

Figure 1 - Photomicrographs of the $A$. gemmatalis midgut showing alterations from the following treatments: BRS 257 (control) (A); BR 16 (B); Dowling (C); PI 229358 (D); IAC 100 (E); PI 227687 (F).
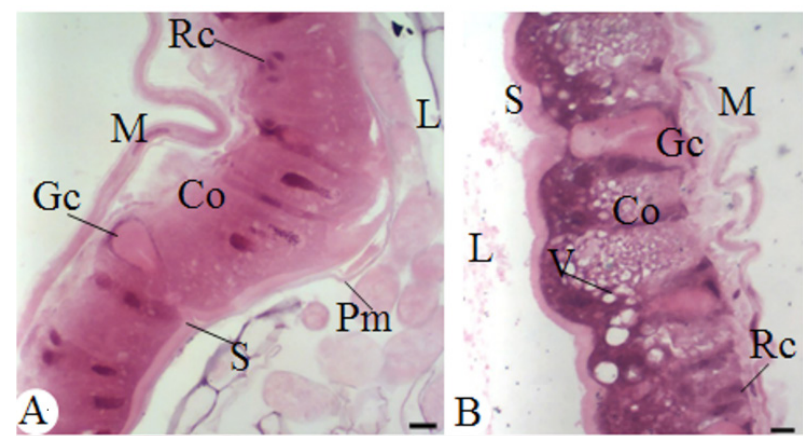


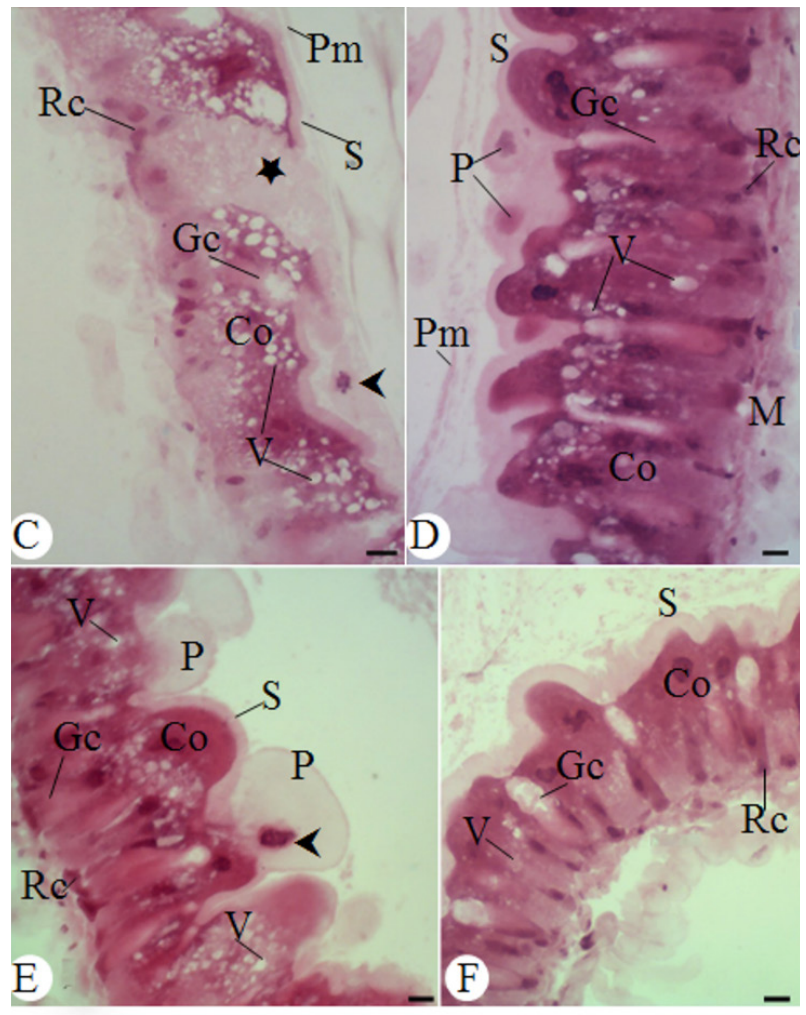

Legend: Columnar cells (Co), cytoplasmic vacuoles (V), striated border (S), cytoplasmic protrusions (P) sometimes with nucleus $(\star)$, goblet cells $(\mathrm{Gc})$, regenerative cells $(\mathrm{Rc})$, muscular layer $(\mathrm{M})$, peritrophic membrane (Pm), lumen (L). Note total cell detachment (૪) to lumen. Bar $=10 \mu \mathrm{m}$

Source: Authors

\section{Discussion}

In larvae treated with BRS 257 (control), the midgut wall presented an epithelial layer, covered by a peritrophic membrane and surrounded by a muscular layer, similar to described by several authors in others Lepidopteran species (CHAPMAN, 2013; LEVY et al., 2004; LEVY et al., 2009; SOUSA et al., 2009).

Apical cytoplasmic protrusion released to the lumen was characteristic in all the treatments, but there was an apparent increase of these structures according to concentration of genistin and rutin when compared with the control. In midgut of $A$. gemmatalis infected by $A g M N P V$, Levy (2005) observed the same cellular degradation followed by cell regeneration, allowing the recovery of epithelial tissue against infection by the virus. Washburn, Wong e Volkman (2001) also noted these cytoplasmic columnar portions which considered it as a mechanism of resistance against infection by viruses. Hakim, Baldwin e Smagghe (2010) informs that the protuberances may be associated with cell death, once when the midgut is infected with microbial agents, the columnar cells swell and form apical protuberances releasing their entire contents into the lumen. Another aspect was related by Cristofoletti, Ribeiro and Terra (2001) and Pinheiro, QuagioGrassiotto and Gregório (2008), where the protrusions would be responsible by apocrine secretion of digestive enzymes into the lumen.

Similar aspects have been reported by several authors for various insect species including Helicoverpa armigera (BROOKS et al., 2002); Aedes aegypti (ARRUDA; OLIVEIRA; SILVA, 2008); Apis mellifera (KAKAMAND; MAHMOUD; AMIN, 2008); Spodoptera frugiperda (CORREIA et al., 2009); Alabama argilaceae (SOUSA et al., 2009), Plutella xylostella (RIBEIRO et al., 2013) and Spodoptera exigua (ADAMSKI et al., 2016)

The alterations detected in cytoplasm of columnar cells could reflected in the digestive enzyme synthesis and secretion and nutrient absorption, since these cells presented organelles like rough endoplasmic reticulum, pinocytic vesicle, Golgi complex, mitochondria and secretion granules (LEVY, 2005; ADAMSKI et al., 2016).

The striated border and the basal cytoplasmic region of this cell type were intensely altered in the Dowling treatment that only has the genistin isoflavonoid. Damages in the striated border and consequently on the glycoprotein lining of the glycocalyx would also be a crucial factor in their adhesion, recognition capacity and absorption of nutrients. The isoflavonoid genistin (7-O-ß-D-glycoside) was observed in lower concentration in most of leaf extracts of the genotypes that are used by insects control program (PIUBELLI et al., 2005). Salvador (2008) studied the interaction of rutin and genistin, and observed higher mortality, reduction of initial and pupa weights, lower weight gain and growth in A. gemmatalis, besides causing greater morphological changes in midgut. Diets and genotypes containing only genistin did not present antinutritional effect on the insect or any major morphological changes.

Cytoplasmic vacuolization in apical and middle portion of columnar cells was constant in all the treatments, including BR16, considered by Piubelli et al. (2005) as susceptible to A. gemmatalis larvae, since it presents genistin in low concentration. Similar alterations were described by other authors, 
(ADAMSKI et al., 2016; ARRUDA et al., 2008) who studied the cytotoxic effects of substances extracted from plants. Kakamand, Mahmoud and Amin (2008) also detected alteration by using other chemical controlled such as deltamethrin, malathion and thiamethoxam while Ribeiro et al. (2013) detected alteration by using commercial formulations of Bacillus thuringiensis.

According to Appel (1993), the columnar cells alteration could be associated to the process of activating phenolic compounds by oxidation, forming free hydroxyl radicals with toxic action, which would rupture the cell membrane and consequently disturb the insect metabolism.

The goblet cells, although less studied than the columnar, are important cellular type responsible to transport of ions to the midgut lumen. The $\mathrm{K}+$-pump is now known to be composed of two independent counterparts: a vacuolar $\mathrm{H}^{+}$-ATPase (V-ATPase) responsible for the establishment of an $\mathrm{H}+$ gradient and a $\mathrm{K}+/ \mathrm{H}+$ exchanger (WIECZOREK et al., 2009). According to Harvey et al., (2010), the stimulation of nutrient uptake by the presence of a $\mathrm{V}-\mathrm{H}+$-ATPase has subsequently been shown to be a common pattern found in other insect models a characteristic that is not shared by vertebrates. In our work, all the treatments showed damages in goblet cell, especially Dowling and PI 227687, when we could detect cell voluminous and with an apparent increase in the quantity. This aspect could change the midgut alkalinization, and consequently deficiency in food digestion.

Alterations qualitative were also observed in the regenerative cells in insects fed with the BR16, Dowling and PI 227687 genotypes. The most differential aspects noted was that the apparent increase in number was detected especially in genotypes that contained only genistin in their constitution (Dowling). In the future, cell counts studies will be conducted to corroborate our visual observations on the goblet and regenerative cells.

The regenerative cells were shown in cells groups, called regeneration nests, and could be related to the epithelial cell renovation process that consists of substituting older or damaged cells (BILLINGSLEY; LEHANE, 1996; FRANÇA, 2006; ROSTROSZKOWSKA; VILIMOVA; CHAJEC, 2010). This intensive mitotic division is an important way to $A$. gemmatalis larvae in defends itself of compounds like rutin and genistin, as observed by França, (2006) and
Rost-Roszkowska, Vilimova and Chajec (2010), who worked with different controlling agents.

Another significant result noted was the fragmentation the peritrophic membrane of midgut of larvae fed with BR16, Dowling and PI229358 genotypes and/or its absence in those fed with the IAC 100 and PI 227687 genotypes. This membrane consists of a fine network composed of chitin, glycosaminoglycans, glycoproteins and proteins (LEVY et al., 2004; LEVY et al., 2009; TERRA, 2001). It has a role in preventing mechanical injuries to the MI epithelial cells and responsible for the compartmentalization of digestion and protection against microorganisms and toxins ingested along with food (TERRA, 2001). Thus, the rupture of this structure could be associated with the intense disorganization of the columnar cells and consequently your synthesis.

\section{Conclusions}

In this study we can conclude, through morphological analysis, that there were great alterations in the epithelium of $A$. gemmatalis larvae in all the treatments tested. We also observed that these alterations occurred principally in the columnar cells which showed intense vacuolization and increase in protrusions released towards the lumen, and in goblet cells which increase in number. The regenerative cells and peritrophic membrane were also modified in some genotypes tested, indicating that the compounds rutin and genistin can affect the digestion and development in A. gemmatalis larvae, even leading to death. Generally, among the genotypes tested, those that caused the greatest alterations were Dowling and PI 227687. These data may be utilized as an additional tool to control this pest in the soybean, either as recommended cultivars or for genetical enhancement.

\section{Acknowledgements}

We gratefully acknowledge Centro Nacional de Pesquisa da Soja (Embrapa Soja), Londrina, PR, for supplying $A$. gemmatalis larvae and genotypes. This work was partially supported by Coordenação de Aperfeiçoamento de Pessoal de Nível Superior (CAPES). 


\section{References}

ADAMSKI, Z.; RADTKE, K.; KOPICZKO, A.; CHOWANSKI, S.; MARCINIAK, P.; SZYMCZAK, M.; SPOCHACZ, M.; FALABELLA, P.; LELARIO, F.; SCRANO, L.; BUFO, S. A. Ultrastructural and developmental toxicity of potato and tomato leaf extracts to beet armyworm, Spodoptera exigua (Lepidoptera: Noctuidae). Microscopy Research and Technique, Genoa, v. 79, p. 948-958, 2016.

APPEL, H. M. Phenolics in ecological interactions: the importance of oxidation. Journal of Chemical Ecology, Philadelphia, v. 19, p. 1521-1551, 1993.

ARRUDA, W.; OLIVEIRA, G. M.; SILVA, I. G. Estudo ultraestrutural do efeito da toxicidade do extrato da Magonia pubescens (ST. HILL) no mesêntero de larvas de Aedes aegypti (L.) (Díptera: Culicidae). Revista de Patologia Tropical, Goiânia, v. 37, p. 255-267, 2008.

BILLINGSLEY, P. F.; LEHANE, M. J. Structure and ultrastrucutre of the insect midgut. In: LEHANE, M. J; BILLINGSLEY, P. F. Biology of the insect midgut. Londres: Chapman \& Hall, 1996. p. 3-25.

BROOKS, E. M.; GORDON, K. H. J.; DORRIAN, S. J.; HINES, E. R.; NANZLIK, T. N. Infection of its lepidopteran host by Helicoverpa armigera Stunt virus (Tetraviridae). Journal of Invertebrate Pathology, Urbana, v. 80, p. 97-111, 2002.

CHAPMAN, R. F. The insects: structure and function. 5. ed. Cambridge: Harvard University Press, 2013.

CORREIA, A. A.; WANDERLEY-TEIXEIRA, V.; TEIXEIRA, A. A. C.; OLIVEIRA, J. V.; TORRES, J. B. Morfologia do canal alimentar de lagartas de Spodoptera frugiperda (J.E. SMITH) (Lepidoptera: Noctuidae) alimentadas com folhas tratadas com nim. Neotropical Entomology, Londrina, v. 38, p. 83-91, 2009.

CRISTOFOLETTI, P. T.; RIBEIRO, A. F.; TERRA, W. T. Apocrine secretion of amylase, exocytosis of trypsin along the midgut of Tenebrio molitor larvae. Journal of Insect Physiology, Portici, v. 47, n. 2, p. 143-155, 2001.
FRANÇA, A. A. P. Regenerative cells in the midgut of Meliphona quadrifasciata anthidioides (Hymenoptera, Apidae Melliponini): a comparative study of workers and quens. Brazilian Journal of Morphological Sciences, São Paulo, v. 23, p. 401-404, 2006.

HAKIM, R. S.; BALDWIN, K.; SMAGGHE, G. Regulation of midgut growth, development, and metamorphosis. Annual Review of Entomology, Urbana, v. 55, p. 593-608, 2010.

HARVEY, W. R.; OKECH, B. A.; LINSER, P. J.; BECNEL, J. J.; AHEARN, G. A.; STERLING, K. M. H. (+) v-ATPase-energized transporters in brush border membrane vesicles from whole larvae of Aedes aegypti. Journal of Insects Physiology, Portici, v. 56, n. 10, p. 1377-1389, 2010.

HOFFMANN-CAMPO, C. B. Role of the flavonoids in the natural resistance of soyabean to Heliothis virescens (f.) and Trichoplusia ni (Hübner). 1995. $\mathrm{PhD}$ Thesis. The University of Reading, Reading, 1995.

HOFFMANN-CAMPO, C. B.; HARBONE, J. B.; MCCAFFERY, A. R. Pre-ingestive and post-ingestive effects of soybean extracts and rutin on Trichoplusia $n i$ growth. Entomologia Experimentalis et Applicata, Netherlands, v. 98, p. 181-194, 2001.

HOFFMANN-CAMPO, C. B.; MAZZARIN, R. M.; LUSTOSA, P. R. Mecanismos de resistência de genótipos de soja: teste de não-preferência para Anticarsia gemmatalis Hübner, 1818 (Lep.: Noctuidae). Pesquisas Agropecuária Brasileira, Brasília, v. 29, p. 513-519, 1994.

HOFFMANN-CAMPO, C. B.; OLIVEIRA, E. B.; MOSCARDI, F. Criação massal da lagarta da soja (Anticarsia gemmatalis). Londrina: Embrapa/Cnpso, 1985.

KAKAMAND, F.; MAHMOUD, T. T; AMIN, A. B. B. The role of three insecticides in disturbance the midgut tissue in honey bee Apis mellifera L. workers. Journal of Duhok University, Duhok, v. 11, p. 144-151, 2008.

KUBO, I.; HANKE, F. G. Chemical methods for isolating and identifying phytochemicals biologically active in insects. In: MILLER, J. R.; MILLER, T. A. (Ed.). Insects-plant interactions. New York: SpringVerlag, 1986. p. 121-153. 
LARA, F. M. Princípios de resistência de plantas a insetos. São Paulo: Ícone, 1991.

LEVY, S. M. Susceptibilidade/ resistência de larvas de Anticarsia gemmatalis Hübner, 1818 (Lepidoptera: Noctuidae) à infecção pelo nucleopoliedrovirus $(A g M N P V)$ : estudo morfológico e detecção de aglutininas no intestino médio. 2005. Tese. Instituto de Biociências, Universidade Estadual Paulista, Botucatu.

LEVY, S. M.; FALLEIROS, A. M. F.; MOSCARDI, F.; GREGÓRIO, E. A.; TOLEDO, L. A. Morphological study of the hindgut in larvae of Anticarsia gemmatalis Hübner (Lepidoptera: Noctuidae). Neotropical Entomology, Londrina, v. 33, p. 427-431, 2004.

LEVY, S. M.; MOSCARDI, F.; FALLEIROS, A. M. F.; SILVA, R. J.; GREGÓRIO, E. A. A morphometric study of the midgut in resistant and non-resistant Anticarsia gemmatalis (Hübner) (Lepidoptera: Noctuidae) larvae to its nucleopolyhedrovirus (AgMNPV). Journal of Invertebrate Pathology, Urbana, v. 101, p. 17-22, 2009.

PINHEIRO, D. O.; QUAGIO-GRASSIOTTO, I.; GREGÓRIO, E. A. Morphological regional differences of epitelial cells along the midgut in Diatraea saccharalis Fabricius (Lepidoptera: Crambidae) larvae. Neotropical Entomology, Londrina, v. 37, n. 4, p. 413-419, 2008.

PIUBELLI, G. C.; HOFFMANN-CAMPO, C. B.; MOSCARDI, F.; MIYAKUBO, S. H.; OLIVEIRA, M. C. N. Are chemical compounds important for soybean resistance to Anticarsia gemmatalis? Journal of Chemical Ecology, Philadelphia, v. 31, p. 1509-1525, 2005.

RIBEIRO, L. M. S.; WANDERLEY-TEIXEIRA, V.; SIQUEIRA, H. A. A.; OLIVEIRA, A. C. B.; LEMOS, A. J. J. M.; TEIXEIRA, A. A. C. Midgut histopathology of resistant and susceptible Plutella xylostella exposed to commercial formulations of Bacillus thuringiensis. Bulletin of Insectology, Bologna, v. 66, n. 1, p. 161171, 2013.
ROST-ROSZKOWSKA, M. M.; VILIMOVA, J.; CHAJEC, L. Fine structure of the midgut epithelium of Atelura formicaria (Hexapoda: Zygantoma: Ateluridae), with special reference to its regeneration and degeneration. Zoological Studies, Taiwan, v. 49, p. 10-18, 2010.

SALVADOR, M. C. Efeito de genótipos de soja e de flavonoides na biologia e no intestino médio de Anticarsia gemmatalis. 2008. Dissertação (Mestrado em Entomologia Agrícola) - Faculdade de Ciências Agrárias e Veterinárias, Jaboticabal, 2008.

SOUSA, M. E.; WANDERLEY-TEIXEIRA, V.; TEIXEIRA, A. A.; SIQUEIRA, H. A.; SANTOS, F. A.; ALVES, L. C. Ultrasctructure of the Alabama argilacea (Hübner) (Lepidoptera: Noctuidae) midgut. Micron, Sydney, v. 40, p. 743-749, 2009.

STAMP, N. E.; SKROBOLA, K. L. Failure to avoid rutin diets results in altered food utilization and reduced growth rate of Manduca sexta larvae. Entomologia Experimentalis et Applicata, Netherlands, v. 68, p. 127-142, 1993.

TERRA, W. R. The origin and functions of the insect peritrophic membrane and peritrophic gel. Archives of Insect Biochemistry and Phisiology, Columbia, v. 47, n. 2, p. 47-61, 2001.

TERRA, W. R.; FERREIRA, C. A digestão dos insetos. Ciência Hoje, Rio de Janeiro, v. 12, p. 28-38, 1991.

VALLE, G. E.; LOURENÇÃO, A. L. Resistência de genótipos de soja a Bemisia tabaci (Genn.) biótipo B (Hemiptera: Aleyrodidae). Neotropical Entomology, Londrina, v. 31, p. 285-295, 2002.

WASHBURN, J. O.; WONG, J. F.; VOLKMAN, L. E. Comparative pathogenesis of Helicoverpa zea nucleopolyhedrovirus in noctuid larvae. Journal of General Virology, London, v. 82, n. 7, p. 1777-1784, 2001.

WIECZOREK, H.; BEYENBACH, K. W.; HUSS, M.; VITAVSKA, O. Vacuolar-type proton pumps in insect epithelia. Journal of Experimental Biology, Bern, v. 212, p. 1611-1619, 2009.

Recebido em: 31 ago. 2017 Aceito em: 09 out. 2017 
Cruz, N. A.; et al. 